\title{
Sistem Penghantaran Obat Baru Nanopartikel Hibrid Lipid-Polimer
}

\author{
Maria Elvina Tresia Butarbutar \\ Program Studi Magister Farmasi, Fakultas Farmasi, Universitas Padjadjaran, Sumedang 45363 \\ email: mariaelvinatresia@gmail.com \\ (Submit 26/5/2019, Revisi 14/7/2019, Diterima 15/7/2019)
}

\begin{abstract}
Abstrak
Terapi menggunakan nanoteknologi dapat meliputi molekul-molekul obat, gen, peptida, RNA, dan sebagai agen diagnostik, serta tidak kalah penting nanoteknologi dapat meningkatkan indeks terapetik dan farmakokinetik obat pada sistemik. Lipid-polimer hibrid nanopartikel adalah struktur nanopartikel yang teridiri dari liposom dan polimer. Polimer sebagai inti dan lipid sebagai lapisan terluar. Dalam mini artikel review ini, nanopartikel hibrid lipid-polimer dijelaskan terkait metode pembuatan, mekanisme pembentukan, dan contoh aplikasinya.
\end{abstract}

Kata kunci : sistem penghantaran obat, nanopartikel, hibrid lipid-polimer

\section{Outline}

- Pendahuluan

- Terapi menggunakan nanoteknologi

- Parameter Nanopartikel

- Keuntungan Nanopartikel

- Polimer pembawa nanopartikel Polimer Nanopartikel

- Lipid-Polimer Hibrid Nanopartikel

- Mekanisme Pembentukkan LPHNPs

- Metode Preparasi LPHNPs

- Aplikasi Preparasi LPHNPs Satu Langkah

- Aplikasi Preparasi LPHNPs Dua Langkah

- Contoh Penghantaran Obat Tertarget Oleh LPHNPs

- Aplikasi LPHNPs Dalam Penghantaran Obat Tertarget

- Kesimpulan

- Daftar Pustaka

\section{Pendahuluan}

Nanoteknologi adalah suatu platform yang berpotensi sebagi pembawa atau carrier suatu obat (zat aktif / zat terapetik). Perkembangan nanoteknologi yang struktur molekul berukuran < $1000 \mathrm{~nm}$ telah berhasil memerangi sejumlah besar penyakit, seperti kanker dan penyakit kardiovaskular. Dengan demikian, tidak mengherankan jika nanoteknologi telah banyak digunakan sebagai carrier obat. 


\section{Terapi menggunakan nanoteknologi}

Terapi menggunakan nanoteknologi dapat meliputi molekul-molekul obat, gen, peptida, RNA, dan sebagai agen diagnostik, serta tidak kalah penting nanoteknologi dapat meningkatkan indeks terapetik dan farmakokinetik obat pada sistemik.

Penerapannya obat dienkapsulasi di dalam pembawa yang berukuran nanopartikel atau dapat juga dikonjugasi pada permukaan pembawa. Obat dikendalikan oleh formulasi matriks dan dapat dipengaruhi oleh $\mathrm{pH}$ dan suhu lingkungan.

\section{Parameter Nanopartikel}

Melihat begitu besar potensi yang dimiliki oleh nanopartikel sebagai agen pembawa obat, perlu diperhatikan beberapa parameter keberhasilan nanopartikel, yaitu:

- Ukuran, ukuran yang kecil memungkinkan pengiriman obat bertarget memiliki efektivitas terapi yang lebih tinggi.

- Pembawa harus bersifat inert untuk menghindari interaksi dengan obat.

- Homogen

\section{Keuntungan Nanopartikel}

Beberapa keuntungan penggunaan nanopartikel sebagai pembawa, di antaranya:

- Memperbaiki sifat farmakokinetik dan farmakodinamik obat tanpa merubah struktur obat.

- Meningkatkan efektivitas terhadap jaringan, penargetan jaringan, dan penargetan molekul.

- Memiliki kemampuan untuk menghindari obat dari hambatan biologis.

- Meningkatkan indeks terapetik obat.

- Dapat pengirimkan beberapa obat yang sifat fisika kimianya berbeda.

\section{Polimer pembawa nanopartikel}

Polimer secara kimia terdiri dari unit struktural monomer yang berulang yang saling berikatan dalam satu rantai. Contoh polimer, misalnya polimer nanopartikel, misel polimer, dan dendrimers. Contoh lipid, misalnya liposom, solid lipid nanoparticle, dan contoh logam, misalnya emas, silika. Beberapa contoh yang telah disebutkan telah banyak digunakan sebagai pembawa berukuran nano (nanocarrier).

Sifat in vivo nanocarrier dapat disesuaikan dengan beberapa teknik modifikasi, seperti:

- Jangka waktu dan stabilitas saat dirilis.

- Kemampuan penargetan.

- Kemampuan mendiagnosa.

- Kepekaan terhadap rangsangan. 


\section{Polimer Nanopartikel}

Polimer nanopartikel telah banyak digunakan dan menunjukkan integritas struktural yang tinggi, memiliki kemampuan rilis terkontrol, dan stabilitas yang baik selama penyimpanan. Selain itu, polimer nanopartikel juga mudah dipersiapkan untuk pengiriman obat bertarget. Hal ini membuat polimer nanopartikel sangat menarik untuk dijadikan sebagai pembawa obat terapetik.

\section{Lipid-Polimer Hibrid Nanopartikel}

Lipid-polimer hibrid nanopartikel adalah struktur nanopartikel yang teridiri dari liposom dan polimer. Polimer sebagai inti dan lipid sebagai lapisan terluar.

Karakteristik dari komponen nanopartikel ini menunjukkan stabilitas fisik yang baik dan biokompatibilitas. Secara signifikan, strategi ini menunjukkan hal positif nanopartikel sebagai pembawa obat. Walaupun telah banyak menunjukkan kelebihan, strategi ini belum banyak diterapkan.

Strategi persiapan lipid-polimer hibrid nanopartikel ini dapat dibedakan menjadi dua, yaitu metode satu langkah dan metode dua langkah. Metode yang digunakan bergantung pada kebutuhan. Aplikasi LPHNPs ini juga telah mencapai terapi antikanker, genetik, vaksin, dan diagnostic.

\section{Mekanisme Pembentukkan LPHNPs}

Seperti yang telah disebutkan di atas bahwa LPHNP menggabungkan dua nanopartikel liposom dan polimer.

LPHNP tersusun dari tiga bagian, yaitu:

- Inti polimer, yang berfungsi membungkus obat.

- Satu lipid monolayer, yang mengelilingi inti polimer.

- Lipid terluar (lapisan PEG), yang berfungsi sebagai penstabil dan memperpanjang sirkulasi sistemik LPHNP untuk menghindari kehancurhan kekebalan tubuh.

Bagian lipid monolayer berfungsi menjaga molekul obat untuk mengurangi kehilangan molekul obat saat proses pembuatan. Formulasi LPHNP harus dapat melindungi inti dari degradasi dengan cara mencegah difusi air masuk ke dalam.

\section{Metode Preparasi LPHNPs}

Sampai saat ini, fusi antara lipid dan polimer masih dalam penyelidikan. Misalnya, dalam metode satu langkah, polimer yang mengendap dalam pelarut organik, lalu bila dimasukan ke dalam media air yang mengadung lipid, secara spontan membentuk monolayer dan mengelilingi inti. Lipid-PEG juga membentuk lapisan selama langkah ini, dimana bagian lipid menempel pada permukaan inti polimer dan rantai PEG memanjang secara eksternal menuju bagian hidrofob. 
Lipid-PEG juga dapat dikonjugasikan ke berbagai agen penargetan, seperti asam folat, antibody, arginylglycylaspartic acid (RGD), untuk memastikan pengiriman obat yang ditargetkan.

Metode dua langkah, yaitu metode yang paling umum digunakan dalam proses pengembangan LPHNP. Metode dua langkah ini, polimer nanopartikel dicampurkan dengan lipid, dimana vesikula-vesikula lipid diadsorpsi pada permukaan polimer nanopartikel yang disebabkan adanya interaksi elektrostatik. Polimer nanopartikel biasanya disiapkan dengan proses emulsifikasi, pelarut, penguapan, nanopresipitasi, atau homogenisasi tekanan tinggi.

Metode dua langkah ini, dapat disiapkan dengan membentuk polimer nanopartikel dan ditambahkan ke vesikel lipid, kemudian dibuat dengan hidrasi. Hibrida dibuat dengan adanya energi eksternal saat di vortex atau ultrasonikasi suspensi dan pemanansan pada suhu di atas suhu transisi konstituen lipid. Selanjutnya, lipid dimurnikan dengan cara disentrifugasi.

\section{Aplikasi Preparasi LPHNPs Satu Langkah}

Aplikasi konvensional dengan metode satu langkah ini di antaranya:

- Docetaxel (PLGA - Lecithin/DSPE - PEG)

- Paclitaxel (PLGA - Lecithin/DSPE - PEG)

- $\operatorname{siRNA}(\mathrm{mPEG}-\mathrm{PLA}-\mathrm{BHEM}-\mathrm{Chol})$

- mRNA (PBAE - DOPC, DOTA/DSPE - PEG)

\section{Aplikasi Preparasi LPHNPs Dua Langkah}

- Tumor necrosis factor (Polystyrene - EPC, Chol, Mal - PEG - DSPE)

- Doxorubicin, Combretatin (PLGA - PC, Chol, DSPE - PEG

- Paclitaxel (PLGA - FA - OQLCS, Chol, PEG - OQLCS)

\section{Contoh Penghantaran Obat Tertarget Oleh LPHNPs}

- Curcumin, target RGD (mPEG - PLGA - Lechitin/Cholestrol/Chol - PEG - RGD)

- Doxorubicin HCl, target Folate (PLGA - Lechitin/PEG/DSPE - PEG - FA)

- Pacitaxel, target Folate (PEG/DSPE-PEG/DSPE - PEG - FA)

\section{Aplikasi LPHNPs Dalam Penghantaran Obat Tertarget}

Salah satu aplikasi LPHNPs dalam penghantaran obat tertarget yaitu dalam terapi antikanker. Pengiriman obat ditargetkan dalam kemoterapi untuk meminimalkan efek samping obat kemoterapi terhadapat sel-sel yang sehat, sementara pada saat yang bersamaan harus memaksimalkan paparan obat terhadap sel kanker. 
Dalam hal ini, pengiriman obat terhadap target diformulasikan LPHNP yang memiliki afinitas spesifik terhadap sel kanker, yaitu asam folat. Asam folat adalah salah satu bagian yang produksi berlebih oleh sel kanker. Dalam hal ini, PEG yaitu lapisan terluar dari lipidPEG dari LPHNP dianggap sangat cocok untuk dikonjugasikan pada kelompok target.

Selain folat, RGD juga dapat digunakan sebagai target sel kanker. Beberapa upaya lainnya yang telah dilakukan, yaitu dengan menggunakan transferin dan antibodi sebagai target untuk sel-sel kanker.

\section{Kesimpulan}

Melihat begitu besar potensi yang dimilki oleh LPHNP sebagai platform pengiriman obat, ini dapat dikembangkan lebih lagi terutama dalam studi klinis untuk masa depan dalam jangka waktu yang lama.

Beberapa penjelasan yang telah dijabarkan LPHNPs menunjukkan keberhasilan sebagai platform pembawa obat. Dalam beberapa kasus, LPHNPs memiliki keunggulan dibandingkan dengan hanya menggunakan polimer atau nanopartikel polimer.

Potensi lainnya yaitu LPHNPs dapat dikembangkan dan diproduksi dalam skala industri. Diharapkan ini dapat menjadi salah satu platform masa depan baik dalam bidang farmasi dan klinis.

\section{Daftar Pustaka}

Baghel, S., Cathcart, H., \& O'Reilly, N. J. (2016). Polymeric Amorphous Solid Dispersions: A Review of Amorphization, Crystallization, Stabilization, Solid-State Characterization, and Aqueous Solubilization of Biopharmaceutical Classification System Class II Drugs. Journal of

Pharmaceutical Sciences, 105(9), 2527-2544. doi:10.1016/j.xphs.2015.10.008.

Hadinoto, K., Sundaresan, A., \& Cheow, W. S. (2013). Lipid-polymer hybrid nanoparticles as a new generation therapeutic delivery platform: A review. European Journal of Pharmaceutics and Biopharmaceutics, 85(3), 427-443. doi:10.1016/j.ejpb.2013.07.002.

Mukherjee, A., Waters, A. K., Kalyan, P., Achrol, A. S., Kesari, S., \& Yenugonda, V. M. (2019). Lipid-polymer hybrid nanoparticles as a next-generation drug delivery platform: state of the art, emerging technologies, and perspectives. International Journal of Nanomedicine, Volume 14, 1937-1952. doi:10.2147/ijn.s198353. 